\title{
Renewable Energy Generation in the Energy Balance: the Forecast until 2035
}

\author{
Tetyana V. Pimonenko ${ }^{i}$, Oleksit O. Lyulyovii, Yana O. U $s^{i i i}$, \\ Aleksy S. Kwilinski ${ }^{i v}$ Anastasiya P. Nazarenkov, \\ YULIA O. MYROSHNYCHENKO ${ }^{\text {vi }}$
}

This paper summarizes the arguments and counterarguments within the scientific discussion on developing national economic energy efficiency under optimizing renewable energy generations. This study aims to forecast renewable energy generation until 2035 under the current Ukrainian conditions. The relevance of this scientific issue is the urgency to combat the climate change consequences under economic development. A bibliometric analysis was conducted in the study frameworks to systemize the scientific treatises and indicate main research directions in energy investigation. The source of publications was the Scopus database. The VOSviewer software tools were applied to visualize the obtained results. In turn, to gain the research goal, the authors forecasted the primary energy generations from renewable sources using Autoregressive Integrated Moving Average (ARIMA) model. The study sample was the shares of primary energy from renewable sources in Ukraine. The data covers 19852019. The results of bibliometric analysis allowed identifying main directions in investigating the energy policy such as renewable energy development under climate change; bioenergy; reducing carbon emissions towards economic growth; energy security and policy; management in the energy sector; satisfaction of the energy demand and improving the energy conditions for consumers. In the empirical part of this study, the forecast findings showed the growing tendency in primary energy generation from renewable sources. However, the share of primary energy from renewable sources would increase by 1.16 times $(3,62 \%)$. Therefore, the authors concluded that the target of the Energy Strategy of Ukraine of $25 \%$ the share of primary energy from renewable sources would not be gained until 2035 . This study highlights the necessity to develop renewable energy in Ukraine. The obtained results could be the base for further investigations devoted to elaborating the energy policy towards developing energy efficiency and green development.

Keywords: energy policy, renewable energy, energy strategy, forecast.

Abbreviation:

ARIMA - Autoregressive Integrated Moving Average.

Introduction. The current Ukrainian economy is considered to be low energy-efficient, while the energy-intensive sectors are dominant in the energy structure. Therefore, the energy

\footnotetext{
${ }^{i}$ Tetyana V. Pimonenko, D.Sc. (Economics), Associate Professor, Department of Marketing, Sumy State University;

ii Oleksii O. Lyulyov, D.Sc. (Economics), Professor, Department of Marketing, Sumy State University;

${ }^{\text {iii }}$ Yana O. Us, PhD student, Department of Marketing, Sumy State University;

${ }^{i v}$ Aleksy S. Kwilinsky, D.Sc. (Economics), Professor, The London Academy of Science and Business, United Kingdom;

${ }^{v}$ Anastasiya P. Nazarenko, student, Department of Marketing, Sumy State University;

${ }^{v i}$ Yulia O. Myroshnychenko, Ph.D., Associate Professor, Oleg Balatskyi Department of Management, Sumy State University.
}

(C) T. V. Pimonenko, O. V. Lyulyov, Ya. O. Us, A. S. Kwilinski, A. P. Nazarenko, Yu. O. Myroshnychenko, 2021. https://doi.org/10.21272/mer.2021.92.03

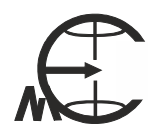


policy of Ukraine showed its inefficiency since the business sector and society isn't motivated to use energy sources rationally. Besides, the government is expected to cover the part of energy cost by subsidies or reduce them. Notably, recently, society tried to keep itself aloof from implementing energy-efficient projects due to the existing stereotype of its inefficiency and energy resources surplus.

In turn, this situation destroys the balance on the energy market. The energy policy mentioned above prevents the national economic energy-efficiency improvement that results in the low-competitive advantages of Ukrainian producers on the international market. Indeed, the nuclear power energy industry covers most of the national economic energy demand. It still is dominant in the Ukrainian energy complex since it ensures sustainability. However, it is worth highlighting the existing urgent problems in the Ukrainian nuclear power industry compromising energy security. Undoubtedly, the current electricity tariff doesn't cover the maintenance expenditure in the nuclear power energy industry. On the other hand, Ukrainian society struggles with a high burden to pay the energy costs. On the other hand, the national economy faces more challenges, such as joining the initiatives in combating and mitigating climate change while reducing $\mathrm{CO} 2$ emissions. In 2009, the UN Framework Convention on Climate Change highlighted the necessity to prevent a temperature rise of more than $2^{\circ} \mathrm{C}$. Thus, it has obligated the participated governments to reduce greenhouse gas emissions. Moreover, in December 2019, the European Commission presented the communique "European Green Deal" to decrease the CO2 emission to zero-level until 2050. In turn, Ukraine, as a potential candidate of the EU union, set a goal of national economic carbon neutrality until 2070.

Following the mentioned above, the Ukrainian energy policy should be modernized to limit greenhouse emissions and implement actions to minimize the negative energy effect on the environment.

Problem statement. The scientists analyzed the issues of energy sector functioning as follows as Alijanova S., Guluzade E., Kolosok S., Nazim, O. H., Palienko M., Krukov Yu Chernyagin D., Kwilinski A., Dzwigol H., etc. The papers [1, 2, 3] analyzed the attraction of investment for the developing energy sector. In the papers $[8,9]$, the scientists analyzed the energy efficiency gaps as a core determinant that provokes the country's declining energy efficiency. Finally, the papers $[13,14,15,16,17,18,19]$ summarised the effective instrument to increase the country's energy efficiency.

In turn, in the study [6], the authors considered the European energy-efficient policy as the primary trigger in developing the energy market and carbon-free economy. Many studies aimed to determine the government policy in minimizing the energy-efficient gaps $[8,13,14$, 23, 2]. The systematization of scientific treatises indicated the essential role of green investments in energy-efficient development. In the publications $[1,15,3]$ the authors analyzed main features and perspectives in attracting green investments at the national and international levels. On the other hand, many scientists devoted their studies to investigating the barriers in promoting the energy-efficiency. Thus, the findings showed that slow energyefficient development has resulted from low green awareness among society [5, 9, 16]. Thus, people believe the implementation of energy-efficient technologies is expensive while the payback period is long. Therefore, it is appropriate to promote green social awareness by applying an effective marketing mechanism $[17,18]$.

The hardly controlled climate change requires the scientific community to elaborate on green economic policy [24, 19]. In the paper [22], the authors highlight the European Green Deal as the main driver of green development. Besides, the authors noted that new European green requirements open the window of opportunities while threatening economic 
Tetyana V. Pimonenko, Oleksii V. Lyulyov, Yana O. Us, Aleksy S. Kwilinski, Anastasiya P. Nazarenko, Yulia O. Myroshnychenko. Renewable Energy Generation in the Energy Balance: the Forecast until 2035

development in countries far away from the green economic transition.

The purpose of this study is to forecast renewable energy generation until 2035 under the current Ukrainian conditions.

Results of the research. This study provides a bibliometric analysis on thematic directions of publications devoted to energy policy. The analysis involved the scientific treatises published in the journals indexed by the Scopus database from 2000 to 2019. The study sample consists of 2000 most cited publications. The search of documents was conducted by the keywords "energy policy" in the documents' titles, keywords, and abstracts. For visualizing the obtained results, the VOSviewer software tools were used.

The finding of the bibliometric analyses allowed identifying six main clusters, which indicate the research directions. Figure 1 demonstrates six main clusters which indicate the research directions. Therefore, the first main cluster shows the research interest in studying renewable energy development under climate change. The second cluster involved the publications addressed to developing bioenergy. The third cluster focused on studying the reducing carbon emissions towards economic growth. The fourth cluster is devoted to developing energy security and policy in gaining sustainability. The fifth cluster indicates the research direction in elaborating on management in the energy sector under renewable energy. Finally, the sixth cluster combines the publications in satisfying the energy demand and improving the energy conditions for consumers.

Besides, it is worth considering the evolutionary development of research formation in investigating the energy policy. Thus, it could be concluded that climate changes have boosted the scientific activity in studying energy policy since 2013.

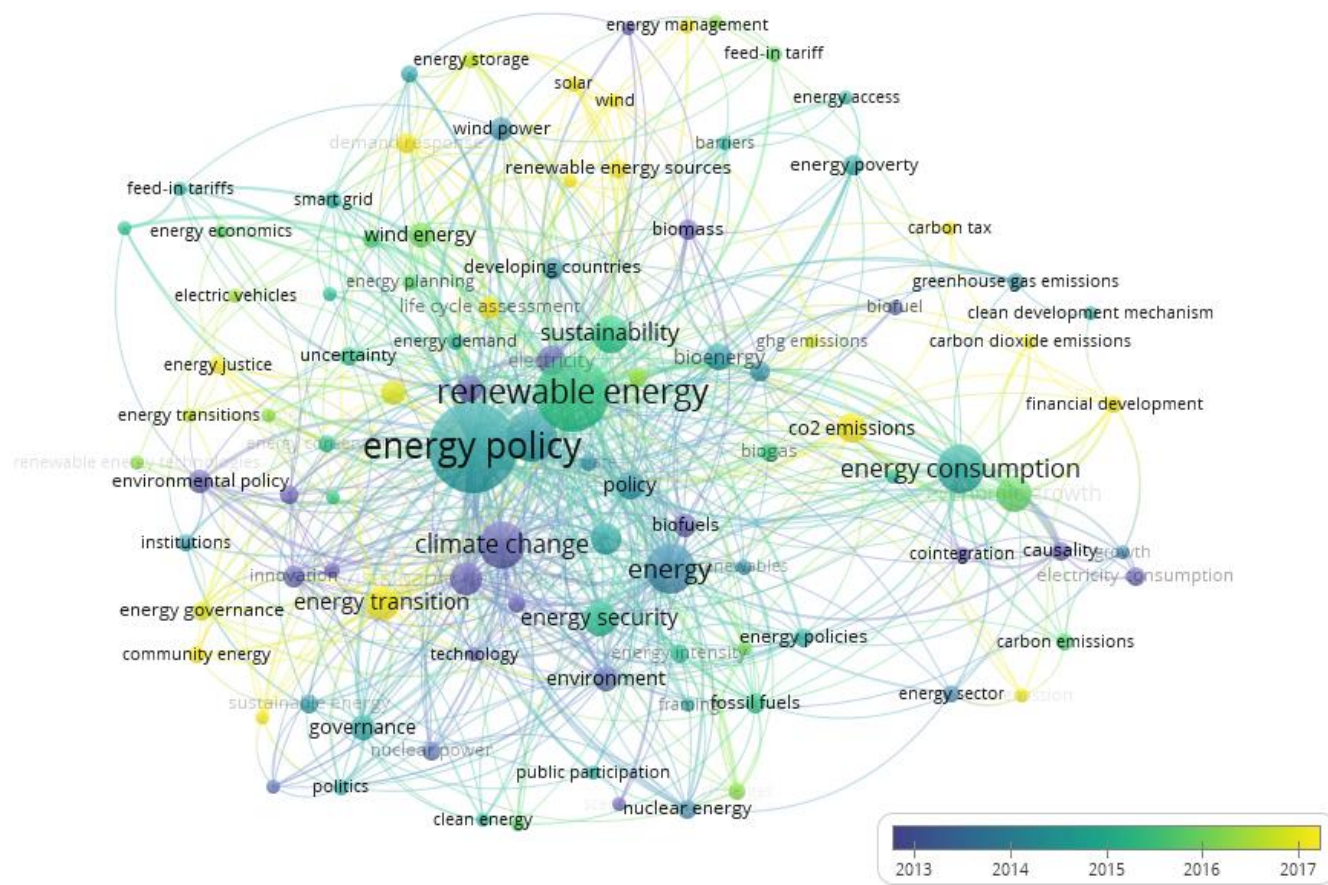

Figure 1. The network map of evolutionary keywords co-occurrences 
Т. В. Пімоненко, О. В. Люльов, Я. О. Ус, О. С. Квілінські, Ю. О. Мирошниченко. Виробництво енергії з відновлюваних джерел в енергетичному балансі України: прогнозування до 2035 року

[developed by the author based on the Scopus data]

In turn, the scientists started investigating bioenergy, technological development. Since 2014 the researchers have focused on developing energy policy, sustainability, greenhouse gas emissions, etc. In 2015-2016, the studies were addressed to determine the relationship between renewable energy development and economic growth. In turn, the researches dated after 2017 covers the issues of energy transitions, renewable energy development, and $\mathrm{CO} 2$ emissions, etc. It stands to mention the studying the energy policy is multidisciplinary. Following the Scopus analysis results, $29.7 \%$ of publications are indexed in Energy subject area, $18.6 \%$ Environmental Sciences, $16.9 \%$ - Engineering, $6.7 \%$ - Social Sciences, $5.3 \%$ - Computer Sciences, $3.3 \%$ - Business, Management and Accounting, $3.2 \%$ - Economics, Econometrics and Finance, $2.9 \%$ - Mathematics, $2.4 \%$ - Earth and Planetary Sciences; $2.2 \%$ - Materials Science, $8.8 \%$ - other.

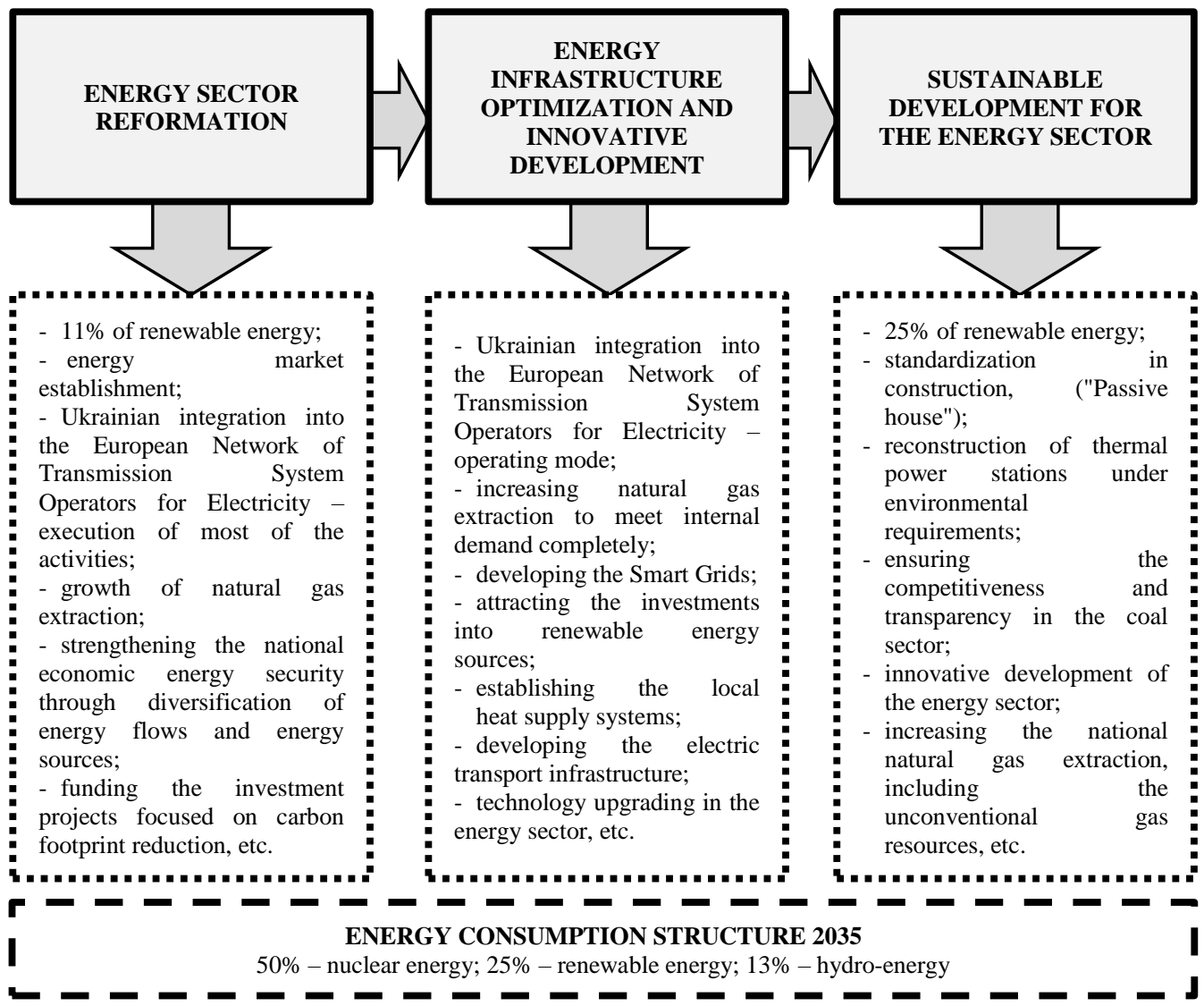

Figure 2. Priorities of the Energy Strategy of Ukraine until 2035

[systemized by the authors based on $[11,4]$ 
Tetyana V. Pimonenko, Oleksii V. Lyulyov, Yana O. Us, Aleksy S. Kwilinski, Anastasiya P. Nazarenko, Yulia O. Myroshnychenko. Renewable Energy Generation in the Energy Balance: the Forecast until 2035

Having concluded the EU association agreement, Ukraine reprioritized its social and economic development strategy, particularly under energy policy. Thus, Ukraine is to change its approaches to energy policy formation to align with the EU principles and requirements. Therefore, the government approved the Energy Strategy of Ukraine until 2035. It stands to note that this document focused on gaining the energy goals through formalizing the government policy, setting the tasks, and developing the mechanisms to synchronize all stakeholders such as government, business, and society. Notably, the Energy Strategy of Ukraine until 2035 provides three implementation stages dated by the periods until 2020, 2025, and 2035 (Fig. 2).

Thus, the first stage is to reform the energy sector until 2020; the second is to optimize and boost the innovation development until 2025; the third stage should result in the sustainable development of the energy sector. On the other hand, the Energy Strategy of Ukraine until 2035 focused on economic growth and social welfare. Fig. 3 demonstrates the slight growing tendency in GDP. In turn, the Energy Strategy of Ukraine provides the ambitious target to increase the GDP by two times by 2035 . However, a high share of energy-intensive and lowtech economic sectors are the main barriers to boosting GDP. Therefore, reducing energy demand in the real economic sector is one of the priorities for government policy concerning developing the incentive mechanism for energy-efficient growth among energy consumers.

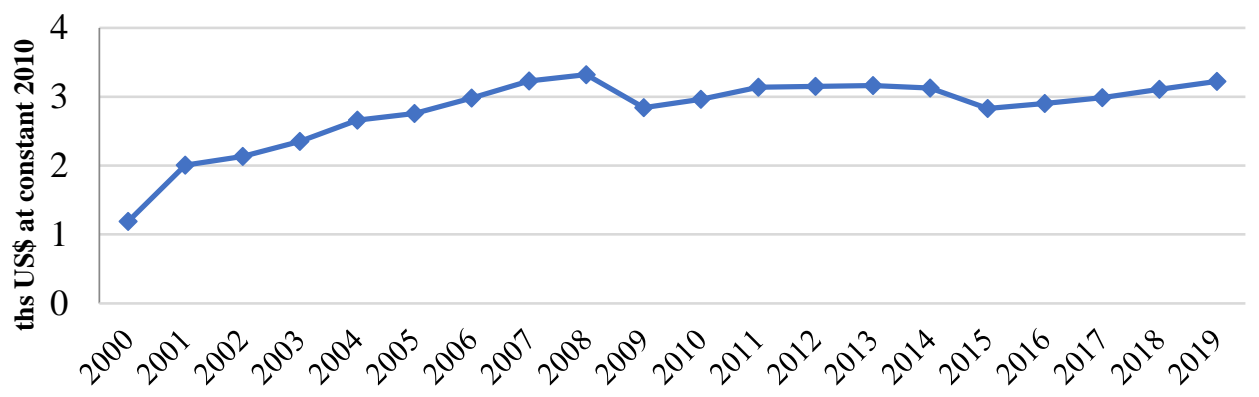

Figure 3. GDP dynamics per capita in Ukraine

[complied by authors based on data from [20]

The obligation to decrease the environmental impact requires Ukraine to additional investments. It is essential to decrease the carbon footprint of the national economic activity by implementing energy-efficient measures and increasing renewable energy generation. As was mentioned above, the share of renewable energy until 2035 should be at least $25 \%$ to ensure national energy security and reducing greenhouse gas emissions.

Figure 4 demonstrates that the growing tendency in generating renewable energy. Thus, in 2019 , the share of primary energy from renewable sources increased by 1.6 times compared to 2000. However, it could be assumed that Ukraine could not target the indicative goal of $11 \%$ by 2020 .

Based on the mentioned above, this study provides the forecast of the share of primary energy from renewable sources until 2035 using Autoregressive Integrated Moving Average (ARIMA) model. Based on the studies [7, 21], the formal $\operatorname{ARIMA}(p, d, q)$ description (1) and the short one (2) are as follows: 
Т. В. Пімоненко, О. В. Люльов, Я. О. Ус, О. С. Квілінські, Ю. О. Мирочниченко. Виробництво енергії з відновлюваних джерел в енергетичному балансі України: прогнозування до 2035 року

$$
\begin{aligned}
& \left(\Delta^{d} X_{t}\right)=\sum_{i=1}^{p} \varphi_{i}\left(\Delta^{d} X_{t-1}\right)+\varepsilon_{t}+\sum_{j=1}^{q} \theta_{j}\left(\Delta^{d} \varepsilon_{t-j}\right), \varepsilon_{t} \sim N\left(0, \sigma_{t}^{2}\right) \\
& \varphi(B)(1-B)^{d} X_{t}=\theta(B) \varepsilon_{t}
\end{aligned}
$$

where $\varphi, \theta$ - polynomials of $p$ and $q$ degrees,

$$
\begin{aligned}
& B \text { - lag operator }\left(B^{j} X_{t}=X_{t-j}, B^{j} \varepsilon_{t-j}, j=0, \pm 1, \ldots\right), \\
& d \text { - sequential difference order }\left(\Delta X_{t}=X_{t-1}-X_{t}=(1-B) X_{t}, \Delta^{2} X_{t}=\Delta^{2} X_{t+1}-\Delta X_{t}=\right. \\
& \left.(1-B)^{2} X_{t}, \ldots\right) .
\end{aligned}
$$

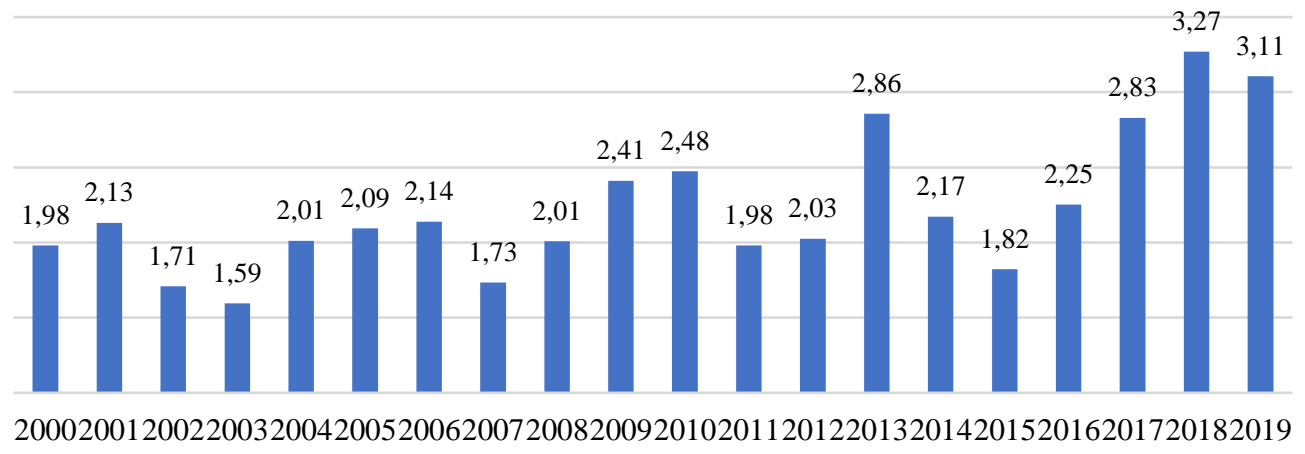

Figure 4 - Dynamic of share of primary energy from renewable sources (1985-2019) [developed by the authors based on [12]

In turn, the empirical study is conducted by the Eviews software. The study sample is the shares of primary energy from renewable sources in Ukraine. The study period is 1985-2019.

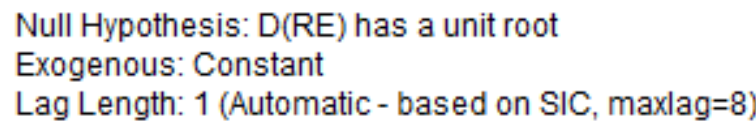

\begin{tabular}{lccc}
\hline \hline & t-Statistic & Prob. \\
\hline \hline Augmented Dickey-Fuller test statistic & -7.025673 & 0.0000 \\
\hline Test critical values: $\quad 1 \%$ level & -3.653730 & \\
& $5 \%$ level & -2.957110 & \\
& $10 \%$ level & -2.617434 & \\
\hline
\end{tabular}

Figure 5. Augmented Dickey-Fuller (ADF) unit root test [formulated by the authors using the Eviews software]

It is worth mentioning that building an ARIMA model requires a stationarity time series check. Thus, the Augmented Dickey-Fuller (ADF) unit root test was applied. According to the ADF-test, the time series is nonstationary since the t-statistic value is a higher critical value. 
Tetyana V. Pimonenko, Oleksii V. Lyulyov, Yana O. Us, Aleksy S. Kwilinski, Anastasiya P. Nazarenko, Yulia O. Myroshnychenko. Renewable Energy Generation in the Energy Balance: the Forecast until 2035

For obtaining a stationary series, the operator of taking successive differences was used. Figure 5 presents the results.

Then, the model parameters were evaluated, and series of residuals were analyzed to check the model for adequacy after obtaining the stationary series.

Figure 6 demonstrates the forecast of the share of primary energy from renewable sources until 2035. The obtained results showed the growing tendency to generate primary energy from renewable sources in the future. Thus, in 2035 the share of primary energy from renewable sources would increase by 1.16 times $(3.62 \%)$. However, Ukraine would not archive the target of $25 \%$ of primary energy from renewable sources. The findings highlight the necessity to reconsider the national energy policy and implement social and economic reforms to boost renewable energy generation.

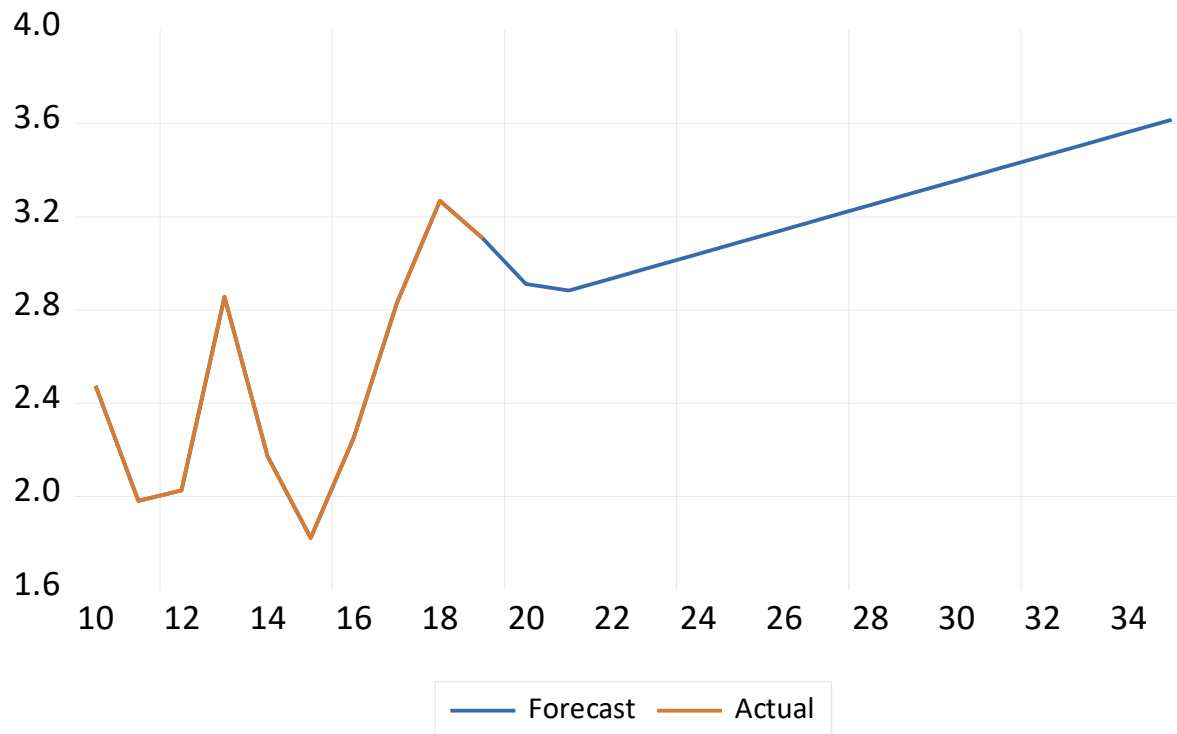

Figure 6. Forecast of share of primary energy from renewable sources, $\%$ [developed by the authors based on the data from [12]

Indeed, the government policy should promote international cooperation to attract potential international investors and donors into the renewable energy market of Ukraine; expand renewable energy power generation; providing the incentive mechanisms in implementing solar and wind power stations; increasing the bioenergy consumption in industries; increasing the social awareness about the environmental and economic benefits from renewable energy, etc.

Conclusions and prospects of further research. Following the obtained results showed that Ukraine would not gain the target of $25 \%$ of primary energy from renewable sources until 2035. Therefore, it requires energy policy improvement to deform the real economy towards decreasing resource- and energy-intensive activities by implementing modern energyefficient technologies, rational use of energy resources, optimizing energy infrastructure, etc.

Besides, it is appropriate to improve the economic incentive mechanism to stimulate the reorientation of business and society on the energy-efficient model. In this case, the 
government should provide the institutional conditions for energy consumers to invest in energy efficiency.

Acknowledgements. This research was funded by grants from the National Research Foundation of Ukraine (0120U104807).

\section{References}

1. Chygryn, O. (2012). Problems of assessing the enterprise investment attractiveness. Proceedings of All-Ukrainian scientific-practical conference (with international participation "Investment and innovation strategy of enterprise development", Zhytomyr, 55-56.

2. Chygryn, O. \& Pimonenko, T. (2011). Ecological and economic aspects of introduction of modern instruments of ecopolitics in the corporate sector. Proceedings of the University of the State Fiscal Service of Ukraine, (1), 602-614.

3. Chygryn, O., Krasniak, V. (2015). Theoretical and applied aspects of the development of environmental investment in Ukraine. Marketing and Managements of Innovations, 3, 226-234.

4. Energy Strategy of Ukraine until 2035 (2021). White Book of Ukrainian Energy Policy "Security And Competitiveness". Retrieved from: https://ips.ligazakon.net/document/NT1202.

5. Hakimova, Y., Samusevych, Y., Alijanova, S., \& Guluzade, E. (2021). Eco-Innovation VS. Environmental Taxation: What is More Effective for State Budget? Marketing and Management of Innovations, 1, 312-323. https://doi.org/10.21272/mmi.2021.1-24.

6. Kolosok, S., Pimonenko, T., Yevdokymova, A., Nazim, O. H., Palienko, M., \& Prasol, L. (2020). Energy efficiency policy: impact of green innovations. Marketing and Management of Innovations, 4, 50-60. https://doi.org/10.21272/mmi.2020.4-04.

7. Krukov, Yu., and Chernyagin, D. (2011). An Arima model for forecasting a values of network traffic. Journal of Information Technologies and Computing Systems, 2, 41-49.

8. Lyulyov, O., Pimonenko, T., Kwilinski, A., Dzwigol, H., Dzwigol-Barosz, M., Pavlyk, V., \& Barosz, P. (2021). The Impact of the Government Policy on the Energy Efficient Gap: The Evidence from Ukraine. Energies, 14(2), 373.

9. Lyulyov, O., Pimonenko, T., Stoyanets, N., \& Letunovska, N. (2019). Sustainable development of agricultural sector: Democratic profile impact among developing countries. Res. World Econ, 10, 97-105.

10. OECD.Stat (2021). Green Growth Indicators. Retrieved from: https://stats.oecd.org/Index.aspx?DataSetCode=GREEN_GROWTH.

11. Ordinance of the Cabinet of Ministers № 605-p dated on August 18, 2017 On approval of the Energy Strategy of Ukraine until 2035 "Security, energy efficiency, competitiveness". Retrieved from: https://zakon.rada.gov.ua/laws/show/605-2017-\%D1\%80\#Text.

12. Our word in Data (2021). Renewable energy. Retrieved from : https://ourworldindata.org/renewableenergy.

13. Palienko, M., Lyulyov, O., \& Denysenko, P. (2017). Fiscal Decentralisation as a Factor of Macroeconomic Stability of the Country. Financial markets, institutions and risks, (1, Is. 4), 74-86.

14. Panchenko, V., Harust, Yu., Us, Ya., Korobets, O., \& Pavlyk, V. (2020). Energy-Efficient Innovations: Marketing, Management and Law Supporting. Marketing and Management of Innovations, 1, 256-264. https://doi.org/10.21272/mmi.2020.1-21.

15. Pimonenko T., Us J., Leus D., Fedyna S. (2017). The modern ecological and economic instruments for sustainable development. Visnyk of Sumy State University. Economy series, 2, 57-67.

16. Pimonenko, T, Lyulyov, O., Us, Ya. (2016). Feed-in tariff like an incentive instrument to enlarge renewable energy using by households. Proceedings of XXII International Scientific Conference "Economics for Ecology" ISCS'2016, 78-81.

17. Pimonenko, T., Liuliov, O., \& Us, Y. (2019). Marketing strategies of green investments: basic concepts and specific features. Herald of Ternopil national economic university, (1 (91)), 177-185. 
Tetyana V. Pimonenko, Oleksii V. Lyulyov, Yana O. Us, Aleksy S. Kwilinski, Anastasiya P. Nazarenko, Yulia O. Myroshnychenko. Renewable Energy Generation in the Energy Balance: the Forecast until 2035

18. Pimonenko, T., Lyulyov, O., \& Chygryn, O. (2018). Marketing of green investment: collaboration between main stakeholders. Reporter of the Priazovskyi State Technical University. Section: Economic sciences, 1(36), 214-220.

19. Pimonenko, T., Lyulyov, O., Us, Ya. (2018). Green Development of Small and Medium Enterprises of Ukraine: the EU Experience. Proceedings of the International Scientific Conference "Competitiveness and Innovation in the Knowledge Economy", 2, 28-29 Septembrer 2018, Kishinev, Moldova, p.69-78.

20. The World Bank. (2021). Retrieved https://data.worldbank.org/indicator/NY.GDP.PCAP.KD?locations=UA.

21. Us, Y., Pimonenko, T., \& Lyulyov, O. (2021). Energy efficiency profiles in developing the freecarbon economy: On the example of ukraine and the V4 countries. Polityka Energetyczna, 23(4), 4966. https://doi.org/10.33223/epj/127397.

22. Ziabina, Y., \& Pimonenko, T. (2020). The Green Deal Policy for Renewable Energy: A Bibliometric Analysis. Virtual Economics, 3(4), 147-168.

23. Ziabina, Y., Lyulyov, O., Pimonenko, T. (2019). Development of green energy as a way to energy independence of the national economy: experience of EU countries. SCIentific bulletin of Polissia, 3 (19), 39-48.

24. Ziabina, Ye. (2016). Theoretical Aspects of the Formation of Green Economy in the Context of Sustainable Development. Mechanism of Economic Regulation, 3, 116-121.

Manuscript received 28 February 2021

Mechanism of Economic Regulation, 2021, No 2, 23-32

ISSN 1726-8699 (print)

Виробництво енергії з відновлюваних джерел в енергетичному балансі України: прогнозування до 2035 року

\section{ТЕТЯНА ВОЛОДИМИРІВНА ПІМОНЕНКО*, \\ ОЛЕКСІЙ ВАЛЕНТИНОВИч ЛЮЛЬОВ ${ }^{* *}$ \\ ЯНА ОЛЕКСАНДРІВНА УС ${ }^{* * *}$ \\ ОЛЕКСІЙ СТАНІСЛАВОВИч КВІЛІНСьК ${ }^{* * * *}$, \\ АНАСТАСІЯ ПАВЛІВНА НАЗАРЕНКО ${ }^{* * * * *}$, \\ ЮЛЬЯ ОЛЕКСАНДРІВНА МИРОШНИЧЕНКО ${ }^{* * * * * *}$}

* доктор економічних наук, доцент кафедри маркетингу Сумського державного університету, вул. Р.-Корсакова, 2, м. Суми, 40007, Украӥна,

тел.: 00-380-54-2687934, e-mail: tetyana_pimonenko@econ.sumdu.edu.ua

** доктор економічних наук, доцент кафедри маркетингу Сумського державного університету, вул. Р.-Корсакова, 2, м. Суми, 40007, Украӥна,

тел.: 00-380-54-2687934,e-mail: alex_lyulev@econ.sumdu.edu.ua

**** аспірантка кафедри маркетингу Сумського державного університету,

вул. Р.-Корсакова, 2, м. Суми, 40007, Україна,

тел.: 00-380-98-0618268, e-mail:y.us@fem.sumdu.edu.ua

**** доктор економічних наук, професор Лондонської академії науки і бізнесу,

вул. Бейкер, 120, м. Лондон, W1U 6TU, Англія,

тел.:00-380-54-2687934,e-mail:a.kwilinski@london-asb.co.uk

****** студентка кафедри маркетингу Сумського державного університету вул. Р.-Корсакова, 2, м. Суми, 40007, Украӥна, 
Т. В. Пімоненко, О. В. Люльов, Я. О. Ус, О. С. Квілінські, Ю. О. Мирошниченко. Виробництво енергії з відновлюваних джерел в енергетичному балансі України: прогнозування до 2035 року

******* кандидат економічних наук, доцент кафедри управління імені Олега Балацького

Сумського державного університету,

вул. Р.-Корсакова, 2, м. Суми, 40007, Украӥна,

mел.: +380-542-687878, e-mail: myroshnychenko@management.sumdu.edu.ua

У статті узагальнено аргументи та контраргументи в рамках наукової дискусії щодо енергоефективного розвитку національної економіки при оптимізації виробництва енергії із відновлюваних джерел. Авторами систематизовано основні пріоритети Енергетичної стратегії до 2035 року та інструменти досягнення ії цільових таргетів. Метою дослідження є прогноз питомої ваги відновлюваної енергії в енергетичному балансі національної економіки до 2035 року. У рамках статті проведено бібліометричний аналіз для систематизації наукових досліджень в енергетичній сфері. Мета-дані для бібліометричного аналізу згенеровано з наукометричної бази даних Scopus. Для візуалізації отриманих результатів бібіліометричного аналізу застосовувано програмні засоби Scopus Tools Analysis та VOSviewer. Результати бібліометричного аналізу дозволили визначити основні наукові патерни дослідження енергетичного сектору: розвиток відновлюваної енергетики в умовах зміни клімату; біоенергетика; зменшення обсягів викидів вуглецю; енергетична безпека та політика; управління в енергетичному секторі; задоволення попиту на енергоресурси та зниження енергетичної біності суспільсва в країні Для досягнення мети дослідження авторами використано модель авторегресивної інтегрованої ковзної середньої (Autoregressive Integrated Moving Average, ARIMA) та програмне забезпечення Eviews. Період дослідження 1985-2019 роки. Отримані результати прогнозу засвідчили висхідну тенденцію первинної енергії 3 відновлюваних джерел в енергетичному балансі країни. Однак, частка первинної енергії з відновлюваних джерел зросте 1,16 рази та становитиме 3,62 \%. Таким чином, авторами доведено, що при збереженні наявних тенденцій розвитку енергетичного сектору національної економіки ціль Енергетичної стратегії України у забезпеченні 25 \% первинної енергії з відновлюваних джерел не буде досягнута до 2035 року. Це, у свою чергу, обумовлює необхідність пошуку ефективних механізмів поширення альтернативних джерел енергії у вітчизняній практиці. При цьому уряд країни повинен активізувати свої дії у напрямі формування інституційної інфраструктури для розвитку енергетичного сектору національної економіки.

Ключові слова: енергетична політика, відновлювана енергія, енергетична стратегія, прогноз.

JEL Codes: G1; O44; Q01

Figure: 6, References: 24

Language of the article: English 